\title{
Pair-bond formation and mate fidelity among juvenile Willow
} Tits

\section{Olav Hogstad}

Norwegian University of Science and Technology, Section of Natural History, N-7491 Trondheim, Norway. E-mail: Olav. Hogstad@ntnu.no

\begin{abstract}
Willow Tits Poecile montanus maintain yearlong defence of their territories, and outside the breeding season the territorial pair lives in a "winter flock" with one or two pairs of unrelated juveniles that have settled after post-natal dispersal. Although the pair formation of juveniles involves the process of winter flock formation, it has been suggested that pairing may occur before flock formation. Here I report on 5-6 week old juveniles that form pair-bonds 1-2 weeks after dispersal. This is the first description of mate choice and pair formation of Willow Tits before establishment in a winter flock.
\end{abstract}

Key words: Pair-bond formation; mate fidelity; Willow Tit

\section{INTRODUCTION}

Over $90 \%$ of bird species breed in socially monogamous partnerships. In passerine birds, monogamy varies from one breeding attempt to long-term partnerships (Lack 1968). It is estimated that long-term monogamy occurs in more than $20 \%$ of bird families (Black 1996), the dominant explanation being that reproductive success increases with the duration of partnerships (e.g. Black 1996, Dubois \& Cezilly 2002, Gill 2012).

The Willow Tit Poecile montanus is a monogamous and highly sedentary passerine that maintains a yearlong defence of the territory. Outside the breeding season the adult territorial pair lives in a "winter flock" with two to four subordinate unrelated first-year conspecifics that settle in the flock in August-September after a post-natal dispersal. Since the sex ratio in the majority of such flocks is $1: 1$, it has been concluded that winter flocks are made up of mated pairs (e.g. Ekman 1979, Hogstad 1987, Lahti et al. 1996). A similar pattern is described for other permanent residents such as Crested Tit Lophophanes cristatus (Ekman 1979) and Marsh Tit Poecile palustris (Nilsson 1989a). However, as the number of juveniles produced in an area is larger than the number established in winter flocks in autumn, there is intense competition between juveniles during the winter flock establishment period (Ekman et al. 1981, Nilsson 1989a, Hogstad 1990a). In these species, juvenile males try to become established as soon as possible after independence, while females whose establishment is easier can afford to be selective in their choice of flock mates (Nilsson 1989b).

During the 35 years I have studied the ecology of Willow Tits in a subalpine forest in central Norway, my descriptions of structure and social hierarchies within winter flocks have been based on established flocks. However, some juveniles that I later registered as pairs in winter flocks were observed together as early as in July and August. I therefore suggested (Hogstad 1987), as did Haftorn (1990), that juvenile Willow Tits can form pair-bonds in summer before being established in a winter flock. As the pair formation also involves the process of winter flock formation, it may be difficult to decide whether pairings have occurred before or during flock formation. To verify that pair formation can occur before the flock establishment, the former should be recorded some distance away from the territory in which the birds settle as a paired unit. Furthermore, observations of courtship display associated with the pair formation should strengthen the assumption of a pairing. As quick establishment may be crucial to an individual's dominance position in a flock (e.g. Nilsson \& Smith 1988, Hogstad 1990a) and subsequent survival in its first winter, it seems likely that pair formation should occur within a short time.

In this study, I report observations of four juvenile pair-bond formations established in July, and show that these juveniles later recognized each other as mates in the winter flock. This is the first description of mate choice and pair formation in Willow Tits before establishment in a winter flock.

\section{MATERIAL AND METHODS}

The study was carried out in a subalpine mixed forest composed of Scots Pine Pinus sylvestris and Downy Birch Betula odorata in Budal, in central Norway (c. 63 
${ }^{\circ} \mathrm{N}$ ). In the Budal area, most Willow Tits fledge in the second part of June, and after staying with their parents for about two weeks, they disperse from the parental territory around mid July.

The birds examined in the present study were caught in feeder-traps during 18-25 July 2002 and 2003.They were colour-ringed and their sex determined by a combination of wing-length and body weight measurements (Haftorn1982) and aged as juveniles (born in the same summer) by the shape and abrasion of tail feathers (Laaksonen \& Lehikoinen 1976). The size and composition of the flocks in the area were determined on the basis of coherence among individually colour-ringed birds during July-October (see Ekman 1979). The relative dominance positions of the individuals in each flock were determined by observing winners and losers of interactions at sunflower-seed feeders. The flocks examined in the present study (where the July-birds, hereafter called $\mathrm{m}_{1}$ and $\mathrm{f}_{1}$, were established) consisted of an adult mated pair $(\mathrm{M}=$ male, $\mathrm{F}=$ female $)$, two juvenile males $\left(\mathrm{m}_{1}\right.$ and $\mathrm{m}_{2}$ ) and two juvenile females $\left(\mathrm{f}_{1}\right.$ and $\mathrm{f}_{2}$ ). The adult male was the alpha bird in all flocks. He dominated both of the juvenile males that, in their turn, dominated all females: $\mathrm{M}>\mathrm{m}_{1}>\mathrm{m}_{2}>\mathrm{F}>\mathrm{f}_{1}>\mathrm{f}_{2}$.

To examine whether the birds caught in July recognized each other as mated pairs after being established in a winter flock, I placed $\mathrm{m}_{1}$ and $\mathrm{f}_{1}$ together with the other juvenile pair $\left(m_{2}-f_{2}\right)$ from the same flock in September and the following January in an outdoor aviary (3.5 × $6 \mathrm{~m}$, provided with small trees) situated within the study area. The experiment was carried out four times in September with birds from four different flocks and three times in January with birds from three of the original four flocks. Ten to fifteen minutes after the birds had been placed in the aviary, the reactions of $m_{1}$ and $m_{2}$ to the opposite sex members were recorded by noting the number of times the males were close to a female without showing aggressive behaviour. Every minute during a trial of 10 minutes for each flock, the following score was made: 1 if $\mathrm{m}_{1}$ or $\mathrm{m}_{2}$ was $<1$ $\mathrm{m}$ from $\mathrm{f}_{1}$ and/or $\mathrm{f}_{2}$, and 0 if either male was $>1 \mathrm{~m}$ from the females. Thus, 40 situations were recorded in September and 30 in January. The duration of each experiment never exceeded 30 minutes. After each experiment, the birds were released back into their territory.

If the juveniles studied were paired, males were predicted to have fewer aggressive encounters towards their mate than towards the other juvenile female in the flock. When the birds attended feeders placed within the territory, I therefore recorded aggressive interactions (chasing the other; making a successful supplanting attack; when approaching, made the other bird to withdraw from a feeder; or cause another bird to wait until it had first fed and then left the feeder) by juvenile males against juvenile females in the flocks described.
Table 1. Number of cases where juvenile male Willow Tits $\left(\mathrm{m}_{1}\right.$ and $\left.\mathrm{m}_{2}\right)$ were close to $(<1 \mathrm{~m})$ subdominant juvenile females from the same winter flock $\left(f_{1}\right.$ and $f_{2}$ ) in an outdoor aviary in September (four flocks) and again in January (three of the same flocks). One situation was recorded every minute during a period of ten minutes, i.e. 40 situations in September and 30 in January.

\begin{tabular}{rrrrr}
\hline & \multicolumn{2}{c}{ September } & \multicolumn{2}{c}{ January } \\
& $\mathrm{f}_{1}$ & $\mathrm{f}_{2}$ & $\mathrm{f}_{1}$ & $\mathrm{f}_{2}$ \\
\hline $\mathrm{m}_{1}$ & 17 & 1 & 11 & - \\
$\mathrm{m}_{2}$ & 0 & 14 & 0 & 5 \\
\hline
\end{tabular}

In total 193 records were made, 122 in September and 71 in January.

\section{RESULTS}

\section{Mate recognition}

After leaving the family flock, i.e. in the dispersal period, juvenile Willow Tits are restless, and the level of aggressiveness near feeder-traps is in general high. During the days before I caught the juveniles examined, I observed only single unmarked birds. Also during the 1-3 hours when I watched different feeder-traps, apparently all unmarked tits that visited feeders were single. Some juvenile males behaved aggressively towards both males and females that tried to enter the feeder. In each of the four cases described below, however, a male and a female behaved as a pair: the female was frequently seen close to the male at the feeder as well as in the field without being attacked by the dominant male, whereas he forced other juveniles to withdraw from the feeder. This association between

Table 2. Number of aggressive encounters (supplanting attacks, chases, displacement of the other bird, or prevention of the other bird from feeding until it had first fed and then left the feeder) by juvenile male Willow Tits $\left(\mathrm{m}_{1}\right.$ and $\left.\mathrm{m}_{2}\right)$ directed towards juvenile females $\left(f_{1}\right.$ and $\left.f_{2}\right)$ when attending a feeder within their flock territories in September and January. Same flocks as in Table 1.

\begin{tabular}{llrrr}
\hline & \multicolumn{3}{c}{ September } & \multicolumn{2}{c}{ January } \\
& $\mathrm{f}_{1}$ & $\mathrm{f}_{2}$ & $\mathrm{f}_{1}$ & $\mathrm{f}_{2}$ \\
\hline & & & & \\
$\mathrm{m}_{1}$ & 18 & 39 & 7 & 11 \\
$\mathrm{~m}_{2}$ & 39 & 26 & 38 & 15 \\
\hline
\end{tabular}


individuals strongly indicates that the juvenile birds had paired. One of the suggested four pairs became established as flock members one day after pairing, the other three on day two or three. The approximate distances between the territories in which they were settled and the catching localities were $300 \mathrm{~m}, 600$ $\mathrm{m}, 600 \mathrm{~m}$ and $1100 \mathrm{~m}$. Thus, the juveniles had to pass through one to three territories when approaching the traps. The four juvenile males $\left(\mathrm{m}_{1}\right)$ that had gained a mate before entering the flocks were socially dominant over the other juvenile male $\left(\mathrm{m}_{2}\right)$ in each of the four established flocks.

When these juveniles were placed in the aviary in September, the juveniles $\mathrm{m}_{1}-\mathrm{f}_{1}$ perched frequently more close to each other than did $\mathrm{m}_{1}-\mathrm{f}_{2}$, and similarly, the juveniles $m_{2}-f_{2}$ perched more often close to each other than $\mathrm{m}_{2}-\mathrm{f}_{1}\left(\chi_{1}^{2}=28.21, \mathrm{p}<0.001\right.$; Table 1$)$. The same pattern was observed in January $\left(\chi_{1}^{2}=16.00, \mathrm{p}<\right.$ 0.001).

When attending a feeder placed within their territories, the $\mathrm{m}_{1}$-juveniles were less aggressive towards $f_{1}$ than towards $f_{2}$, whereas $m_{2}$ was less aggressive towards $f_{2}$ than towards $f_{1}$ in September $\left(\chi_{1}^{2}\right.$ $=9.86, \mathrm{p}=0.002)$ as well in January $\left(\chi_{1}^{2}=6.23, \mathrm{p}=\right.$ 0.013; Table 2).

These results strongly suggest that $\mathrm{m}_{1}-\mathrm{f}_{1}$ and $\mathrm{m}_{2}-$ $\mathrm{f}_{2}$ recognized each other as pairs, and that pair-bonding had occurred before they became established as flock members. If these juveniles $\left(\mathrm{m}_{1}-\mathrm{f}_{1}\right)$ dispersed around mid-July, they formed pair-bonds as early as one to two weeks after leaving their family flocks.

When observed in the field in winter, pair members associated more closely with their partners than with their non-partners. Furthermore, all four pairs $\left(m_{1}-f_{1}\right)$ survived the winter still maintaining their pair-bonds.

\section{Courtship display}

On the day the birds were colour-ringed in July, one of the pairs carried out a display similar to courtship behaviour often observed before breeding. Near a feeder trap, the juvenile female repeatedly approached the male, using appeasement postures by leaning away before she slightly quivered her wings, as if begging for food. The reluctant male ignored her, but after repeated attempts by the female, he responded by giving her pieces of sunflower seeds from the feeder. As far as I know this is the first description of such behaviour outside the breeding season.

\section{DISCUSSION}

Adult territorial Willow Tits experience high annual survival and low territorial turnover (Hogstad in prep.). Because the number of juveniles produced in an area is larger than the number established in winter flocks, constraints may occur for juveniles on resource availability. Such membership in a winter flock, in addition to increasing the probability of settling in an area and thus also the probability of survival through their first winter (Ekman et al. 1981), may be the only way to ownership of a territory (e.g. Hogstad 2003). Thus, selection acts on the young to reach potential establishment sites early (cf. Nilsson 1989a). The juveniles are stressed in this establishment period (Silverin et al. 1984), and chases and even regular fights occur frequently in August and September. It is therefore important to become established as soon as possible after independence and obtain the possibility to settle before potential competitors arrive because early establishment is positively related to dominance. A time difference of one day, or even a few hours, may be sufficient to give dominance asymmetry between individuals (Hogstad 1990b). Once settled as resident members in a winter flock, the juveniles should therefore remain within the territory during the establishment period, i.e. August-October. The relatively long distances between the trapping sites and the territories, as found in the present study, strongly indicates that the juveniles were paired before the flock phase. Leaving the flock territory, even for a short time, may result in loss of membership.

This study shows that pair behaviour in Willow Tits is apparently developed at an early age, and young birds may form pair-bonds when they are about 5-6 weeks old. Since pair-bonds are strong between juvenile birds (Hogstad 1999), it is important to get a high quality mate. Choosing a poor mate can endanger future nesting attempts. Since pair-bond formation occurs early in the autumn, and Willow Tit partnerships often persist for several years (Hogstad in prep.), traits used in assessment of mate quality ought to be good measures in the process of choosing a lifelong mate. If, as found in the Marsh Tit (Nilsson 1989a), the female Willow Tit is the selective sex, food begging behaviour by the female may be an important trait in assessing the male's ability as a later food provisioner during the breeding season. Since juveniles can apparently form pair bonds before establishment in territories of adults, the habitat site may have less impact on mate choice.

Acknowledgements. The manuscript was improved through comments by G. Grønstøl.

\section{REFERENCES}

Black, J.M. 1996. Partnerships in birds. The study of monogamy. Oxford University Press, Oxford.

Dubois, F. \& Cezilly, F. 2002. Breeding success and mate retention in birds: a meta-analysis. Behavioral Ecology and Sociobiology 52: 357-364.

Ekman, J. 1979. Coherence, composition and territories of winter social groups of Willow Tit Parus montanus 
and the Crested Tit P. cristatus. Ornis Scandinavica 10: 56-68.

Ekman, J., Cederholm, G. \& Askenmo, C. 1981. Spacing and survival in winter groups of Willow Tits Parus montanus and Crested Tits P. cristatus - a removal study. Journal of Animal Ecology 50: 1-9.

Gill, S.A. 2012. Testing hypotheses for the evolution of longterm monogamy in Neotropical Buff-breasted Wrens (Cantorchilus leucotis). Journal of Ornithology 153 (Suppl 1): S125-S134.

Haftorn, S. 1982. Variation in body measurements of the Willow Tit Parus montanus, together with a method for sexing live birds and data on the degree of shrinkage in size after skinning. Fauna Norvegica series C, Cinclus 5: $16-26$.

Haftorn, S. 1990. Social organization of winter flocks of Willow Tits, Parus montanus, in a Norwegian subalpine birch forest. Pp. 401-413 in Blondel, J., Gosler, A., Lebreton, J.-D. \& McCleery, R. (eds.): Population biology of passerine birds, an integrated approach. NATO ASI Series, vol. G-24. Springer-Verlag, Heidelberg.

Hogstad, O. 1987. Social rank in winter flocks of Willow Tits Parus montanus. Ibis 129: 1-9.

Hogstad, O. 1990a. Dispersal date and settlement of juvenile Willow Tits Parus montanus in winter flocks. Fauna Norvegica series C, Cinclus 13: 49-55.

Hogstad, O. 1990b. Winter floaters in Willow Tits Parus montanus - a matter of choice or making the best of a bad situation? Pp. 415-421 in Blondel, J., Gosler, A., Lebreton, J.-D. \& McCleery, R. (eds.): Population biology of passerine birds, an integrated approach. NATO ASI Series, vol. G-24. Springer-Verlag, Heidelberg.
Hogstad, O. 1999. Territory acquisition during winter by juvenile Willow Tits Parus montanus. Ibis 141: 615-620.

Hogstad, O. 2003. Strained energy budget of winter floaters in the Willow Tit as indicated by ptilochronology. Ibis 145 online: $1-5$.

Laaksonen, M. \& Lehikoinen, E. 1976. Age determinations of Willow and Crested Tit Parus montanus and P. cristatus. Ornis Fennica 53: 9-14.

Lack, D. 1968. Ecological adaptations for breeding in birds. Methuen, London.

Lahti, K., Koivula, K., Orell, M. \& Rytkönen, S. 1996. Social dominance in free-living Willow Tits Parus montanus: determinants and some implications of hierarchy. Ibis 138: $539-544$.

Nilsson, J.-Å. 1989a. Causes and consequences of natal dispersal in the Marsh Tit, Parus palustris. Journal of Animal Ecology 58: 619-636.

Nilsson, J.-Å. 1989b. Establishment of juvenile Marsh Tits in winter flocks: an experimental study. Animal Behaviour 38: 586-595.

Nilsson, J.-A. \& Smith, H.G. 1988. Effects of dispersal date on winter flock establishment and social dominance in Marsh Tits Parus palustris. Journal of Animal Ecology 57: 917-928.

Silverin, B., Viebke, P.-A. \& Westin, J. 1984. Plasma levels of luteinizing hormone and steroid hormones in freeliving winter groups of Willow Tits (Parus montanus). Hormones and Behavior 18: 367-379.

Received 11 February 2014. Accepted 04 April 2014 